\title{
Genetic Variability and Heritability Studies in Andrographis paniculata Wall. Ex Nees
}

\author{
Hema Devi ${ }^{1}$, Hemant Dhuri ${ }^{1}$, Alice Tirkey ${ }^{1 *}$ and S.S. Porte ${ }^{2}$ \\ ${ }^{1}$ Department of Genetics and Plant Breeding, Indira Gandhi Krishi Vishwavidyalaya, \\ College of Agriculture, Raipur- 492012, Chhattisgarh, India \\ ${ }^{2}$ Department of Soil Science, Indira Gandhi Krishi Vishwavidyalaya, College of Agriculture, \\ Raipur- 492012, Chhattisgarh, India \\ *Corresponding author
}

\begin{tabular}{|c|c|}
\hline \multicolumn{2}{|r|}{ A B S T R A C T } \\
\hline & \multirow{8}{*}{$\begin{array}{l}\text { The extent of variability, heritability and genetic advance for days to } 50 \% \text { flowering, plant } \\
\text { Height }(\mathrm{cm}) \text {, no. of secondary branches / plant, no. of tertiary branches / plant, leaf length } \\
(\mathrm{cm}) \text {, no. of nodes / plant, chlorophyll content (spad), herbage fresh weight }(\mathrm{g}) \text {, herbage dry } \\
\text { weight }(\mathrm{g}) \text {. Whereas, characters, leaf width }(\mathrm{cm}) \text {, petiole length }(\mathrm{cm}) \text {, stem diameter }(\mathrm{cm}) \text {, } \\
\text { internodes length }(\mathrm{cm}) \text {, pod length }(\mathrm{cm}) \text {, no. of seeds/pod, andrographiloide content were } \\
\text { determine in } 134 \text { accession include } 2 \text { checks collected from different district of the } \\
\text { Chhattisgarh along with } 2 \text { check in Anand Kalmegh (Directorate of Medicinal and } \\
\text { Aromatic Plant Board) and Simmegha (Central Institute of medicinal and aromatic plants) } \\
\text { in Andrographis paniculata. Analysis of variance revealed significant differences among } \\
\text { the kalmegh genotype for different Character. Herbage dry weight exhibited maximum } \\
\text { coefficient of variation at both level i.e. genotypic coefficient variation (GCV) and } \\
\text { phenotypic coefficient variation (PCV). High heritability coupled with high genetic advance } \\
\text { as percentage of mean was found in the character no. of tertiary branches/ plant, days to } 50 \\
\% \text { flowering, andrographiloide content followed by herbage dry weight/ plant and plant } \\
\text { height. }\end{array}$} \\
\hline Keywords & \\
\hline & \\
\hline $\begin{array}{l}\text { Andrographiloide, } \\
\text { Heritability, Genetic }\end{array}$ & \\
\hline Advance, Variability. & \\
\hline Article Info & \\
\hline $\begin{array}{l}\text { Accepted: } \\
\text { 15 September } 2017 \\
\text { Available Online: } \\
\text { 10 November } 2017\end{array}$ & \\
\hline & \\
\hline
\end{tabular}

\section{Introduction}

Andrographis paniculata Wall. Ex Nees, commonly known as Kalmegh, King of bitters which belongs to family Acanthaceae is an annual herb of about 30-110 cm height, stem acutely quadangular with many branches widely. Andrographis paniculata is probably native of India and it is distributed throughout Thailand, Peninsular Malaysia to Indonesia. In India it is found in the state of Madhya Pradesh, Chhattishgarh, Odisha, Maharashtra, Assam, Bihar, West Bengal, Uttar Pradesh, Tamilnadu, Kerala (Pandey and Mandal,
2010). Among the diverse plant species, Andrographis contributes more than ten species, such as A. affinis, A. alata, A. beddomei, A. elongata, A. echioides, A. glandulosa, A. lineata, A. ovata, A. paniculata and A. serpyllifolia (Pulliah et al., 2010). It is placed at $17^{\text {th }}$ position among the 32 prioritized medicinal plants of India. It has an important place in the Indian pharmacopoeia and is being prominently used in 26 Ayurvedic formulas (Nandkarni 1954). Leaves, stem, flower, seed, root of the plant is 
being used in various formulation of Indian system of medicine. The leaves and aerial parts of the plant are used in Indian traditional medicine for the treatment of fever, malaria, sore throat (Shanker et al., 2012; Chopra 1956; Mishra 1992; Najib et al., 1999), hepatoprotective, antioxidant (Lin et al., 2009; Tiwari and Rawal, 2001), useful in wounds, ulcers, tonsillitis, osteodynea, menstrual and post partumhacmatometra, hypertension (Puri et al., 1996), blood purifier, liver tonic, jaundice, dermatological diseases, antimicrobial activity (Singha et al., 2003). Antityphoidal property, antibiotic properties (Akbarsha et al., 1990), antihepatotoxic effect (Kapil et al., 1993), Anticancer activity (Kumar, 2004). Antidiabetic (Lal et al., 1986) trail on HIV patient (Calabrese et al., 2000) and found effective etc. The leaves of $A$. paniculata contain the highest amount of andrographolide. Path coefficient analysis facilitate important trait to identify. These parameters vary with the type of material used and the environmental conditions to which the accession are subjected. Fewer studies have been made yet in this regard in the state of C.G.

\section{Materials and Methods}

The 134 accession collected from different district of the C.G. along with 2 check viz, Anand Kalmegh-1 (Directorate of Medicinal and Aromatic Plant Board) and Simmegha (Central Institute of medicinal and aromatic plants) was evaluated.

During kharif 2014-15 all the collected germplasm accession from different location was multiplied to get enough quantity of seed for characterization and evaluation of germplasm for the next year. At the time of maturity the seeds were collected separately of each accession and thus genetic purity was maintained. This seed was sown next year during Kharif was shown in raised bed in nursery and after 30 days the seedling was planted as single seedling per hill in RBD design in two replication. The row to row spacing and plant to plant distance maintained at $30 \mathrm{~cm}$. FYM was applied during the field preparation. Irrigation was given during dry spell. Roger $2 \mathrm{ml} / 5 \mathrm{l}$ water was used to control leaf eating caterpillar at nursery stage. Weeding was done when required to raise good crop.

\section{Results and Discussion}

Analysis of variance of different qualitative and quantitative traits. The average performances of the 134 Kalmegh genotype along 2 checks are shown in the Table 1 .

Analysis of variance worked out for dry herbage weight and its attributing traits a long with quality characters indicated that the mean sum of squares due to genotypes were highly significant for all the characters viz., days to $50 \%$ flowering, plant Height $(\mathrm{cm})$, no. of secondary branches/plant, no. of tertiary branches/plant, leaf length $(\mathrm{cm})$, no. of nodes/plant, chlorophyll content (spad), herbage fresh yield $(\mathrm{g})$, herbage dry yield $(\mathrm{g})$ Significant mean sum of squares due to herbage yield and attributing characters revealed existence of consider able variability in the material studied for the improvement of various traits and better chances of improvement through selection on the basis of these traits.

\section{Estimation of genetic variability}

Genetic parameters of variation are presented in Table 2 for all the characters. The overall mean and rang for dry herbage weight and its components revealed that there is sustainable genetic variability present for most of the characters among the germplasm accession under study. Genetic parameters of variation are discussed character wise. 


\section{Character mean, range}

Days to 50\% flowering ranged from 95 to 168 days with a mean value of 126.76 days. The accession IKM-22 (168 days) was recorded as the late flowering and accession IKM-13 (122 days) was recorded as early flowering.

The plant height ranged from 30.75 to 116.82 $\mathrm{cm}$ with an average plant height $76.22 \mathrm{~cm}$. Among all accession, IKM-14 $(116.82 \mathrm{~cm})$ was recorded as tallest and accession IKM-20 $(30.75 \mathrm{~cm})$ was recorded as the dwarf.

The plant stem diameter ranged from 1.17 to $3.35 \mathrm{~cm}$ with a mean value of plant stem diameter $2.32 \mathrm{~cm}$. Among all accession, IKM$4(3.35 \mathrm{~cm})$ was recorded as long and accession IKM-12 $(1.17 \mathrm{~cm})$ was recorded as the dwarf.

The No. of secondary branches / plant ranged from 22 to 44.50 branches with a mean value of 33.82 branches. The accession IKM -95 (44.50 branches) was recorded as maximum and accession IKM-18 (22 branches) was recorded as the minimum no. of secondary branches / plant.

The no. of tertiary branches / plant ranged from 34.75 to 322.75 with a mean value of 145.94 branches. The accession IKM-75 (322.75 branches) was recorded as maximum and accession IKM-123 (34.75 branches) was recorded as the minimum no. of tertiary branches / plant.

The leaf width of plant ranged from 0.52 to $3.35 \mathrm{~cm}$ with a mean value of $1.53 \mathrm{~cm}$. The accession IKM-2 $(3.35 \mathrm{~cm})$ was recorded as long and accession IKM-33 $(0.52 \mathrm{~cm})$ was recorded as dwarf.

The leaf length of plant ranged from 2.41 to $9.15 \mathrm{~cm}$ with mean value of $6.42 \mathrm{~cm}$. The accession IKM-244 $(9.15 \mathrm{~cm})$ was recorded as long and accession IKM-15 $(0.52 \mathrm{~cm})$ was recorded as short leaf.

The petiole length for the accession ranged from 0.16 to $2.84 \mathrm{~cm}$ with mean value of 1.03 $\mathrm{cm}$. The accession IKM-18 $(2.84 \mathrm{~cm})$ was recorded as highest and accession IKM-141 $(0.16 \mathrm{~cm})$ was recorded as short petiole length.

The no. of nodes / plant ranged from 14.75 to 29.50 nodes with a mean value of 22.15 nodes. The accession IKM -65 (29.50 nodes) was recorded as highest and accession IKM12 (14.75 nodes) was recorded as lowest no. of nodes / plant.

\section{Internodes length $(\mathrm{cm})$}

The internodes length of plant ranged from 1.22 to $4.00 \mathrm{~cm}$ with mean value of $2.74 \mathrm{~cm}$. The accession IKM-194 (4.00 cm) was recorded as long and accession IKM-141(1.22 $\mathrm{cm})$ was recorded as short internodes length.

The average no. of seed/pod was 10 ranging from 10.33 to 11.84 seed / pod. Some accession viz. IKM-9, IKM-38, IKM-39, IKM-43, IKM-62, IKM-64, IKM-67, IKM82, IKM-171, IKM-173, IKM-174, IKM-175, IKM-183, IKM-184, IKM-242 IKM-247, IKM-248 and IKM-253 (11.84) were having maximum no. of seed/pod and accession viz.IKM-260 (10.33) was recorded as lowest no. of seeds / pod.

The length of pod for accession understudy was ranged from 1.64 to $2.21 \mathrm{~cm}$ with mean value of $1.82 \mathrm{~cm}$. The accession IKM-14 $(2.21 \mathrm{~cm})$ was recorded as long and accession IKM-312 $(1.64 \mathrm{~cm})$ was recorded as smallest pod.

The chlorophyll content in leaf (spad) for the accession was ranged from 43.12 to 64.96 with mean value of 56.45 .The accession 
IKM-89 (64.96) was recorded as highest chlorophyll content and IKM-248 (43.12) was recorded as lowest chlorophyll content.

The fresh herbage weight was ranged from 12.60 to $52.70 \mathrm{~g}$ with mean value of $36.42 \mathrm{~g}$. The accession IKM-14 (52.70 g) was recorded as maximum and accession IKM$237(12.60 \mathrm{~g})$ was recorded as lowest fresh herbage weight $(\mathrm{g})$.

The dry herbage weight of leaf was ranged from 6.17 to $46.40 \mathrm{~g}$ with mean value of $29.49 \mathrm{~g}$. The accession IKM-14 (46.40 g) was recorded as maximum and IKM-237 (3.05 g) was recorded as minimum dry herbage weight (g).

The andrographiloide content of leaf for accession ranged from 0.32 to $1.81 \mathrm{mg}$ with mean value of $1.05 \mathrm{mg}$. The accession IKM$269(1.81 \mathrm{mg})$ was recorded as maximum and accession IKM-8, IKM-82 (0.32 mg) were recorded as minimum andrographiloide content in leaf.

All the accessions were recorded when the capsules are fully mature and seed was dry. The visual searing was done. The yellow, yellow brown and brown color was observed in the 134 accession along with 2 checks (NBPGR). The accessions 1 were recorded as yellow, 9 and 247 showed as yellow brown color and accession 231 showed become color.

Out of 134 accessions, 54 accessions were recorded erect type, 64 accessions were recorded as spreading type and 12 were recorded as semi spreading.

\section{Genotypic and phenotypic coefficient of variation}

Genotypic and phenotypic coefficients of variation are simple measure of Variability, these measures are commonly used for the assessment of variability. The relative value of these types of coefficients gives an idea about the magnitude of variability present in a genetic population. Thus, the component of variation such as genotypic coefficient of variation $(\mathrm{GCV})$ and phenotypic coefficient of variation $(\mathrm{PCV})$ were computed.

The phenotypic coefficient of variation (PCV) were marginally higher than the corresponding genotypic coefficient of variation indicated that there is and light influence of environment in the expression of the character like stem diameter, no. of tertiary branches / plant, leaf width, petiole length, leaf length, no. of nodes / plant, internodes length, no. of seeds / pod, pod length and chlorophyll content.

The phenotypic coefficient of variation (PCV) were almost similar to genotypic coefficient of variation (GCV) for days to $50 \%$ flowering, plant height, dry herbage weight, fresh herbage weight indicate that the expression of the character is not influence by the environment. Therefore the genotype is completely expressed in phenotype. Among the different herbage weight attributing traits, dry herbage weight / plant, had highest magnitude of GCV (34.40\%) and PCV $(34.75 \%)$. The high magnitude of GCV (34.12\%) and PCV (34.25\%) was observed for andrographiloide content (mg) followed by no. of tertiary branches / p/ant $(33.48 \%$ to $33.90 \%)$, herbage fresh weight $(27.11 \%$ to $27.63 \%)$, petiole length (23.52\% to 29.94 $\%$, which is indicative of the genetic variability exists in Kalmegh accession.

The moderate GCV and PCV were observed in no. of secondary branches/ plant $(15.21 \%$ to $17.11 \%$ ), days to $50 \%$ flowering ( $13.05 \%$ to $13.11 \%)$, internodes length $(12.48 \%$ to $19.78 \%)$, no. of nodes / plant (12.40\% to $16.11 \%)$. 
Table.1 Analysis of variance for herbage dry weight and its components in kalmegh

\begin{tabular}{|c|c|c|c|c|c|c|c|c|c|c|c|c|c|c|c|c|c|}
\hline $\begin{array}{l}\text { Source } \\
\text { of } \\
\text { variation }\end{array}$ & $\begin{array}{l}\mathrm{D} \\
\mathrm{F}\end{array}$ & $\begin{array}{l}\text { Days to } \\
50 \% \\
\text { flowerin } \\
\mathrm{g}\end{array}$ & $\begin{array}{l}\text { Plant } \\
\text { height } \\
(\mathrm{cm})\end{array}$ & $\begin{array}{l}\text { Stem } \\
\text { Diamet } \\
\text { er } \\
(\mathrm{cm})\end{array}$ & $\begin{array}{l}\text { No. of } \\
\text { secondary } \\
\text { branches/ } \\
\text { plant }\end{array}$ & $\begin{array}{l}\text { No. of } \\
\text { tertiar } \\
\text { y } \\
\text { branch } \\
\text { es/pla } \\
\text { nt }\end{array}$ & $\begin{array}{l}\text { Leaf } \\
\text { width } \\
(\mathrm{cm})\end{array}$ & $\begin{array}{l}\text { Leaf } \\
\text { length } \\
(\mathrm{cm})\end{array}$ & $\begin{array}{l}\text { Petiol } \\
\mathrm{e} \\
\text { Lengt } \\
\mathrm{h} \\
(\mathrm{cm})\end{array}$ & $\begin{array}{l}\text { No. of } \\
\text { Nodes } \\
\text { / } \\
\text { Plant }\end{array}$ & $\begin{array}{l}\text { Intern } \\
\text { odes } \\
\text { length } \\
(\mathrm{cm})\end{array}$ & $\begin{array}{l}\text { No. of } \\
\text { Seeds/ } \\
\text { pod }\end{array}$ & $\begin{array}{l}\text { Pod } \\
\text { Lengt } \\
\mathrm{h} \\
(\mathrm{cm})\end{array}$ & $\begin{array}{l}\text { Chlor } \\
\text { ophyll } \\
\text { Conte } \\
\text { nt } \\
\text { (spad) }\end{array}$ & $\begin{array}{l}\text { Herba } \\
\text { ge } \\
\text { Fresh } \\
\text { Weig } \\
\text { ht } \\
(\mathrm{gm}) \\
\end{array}$ & $\begin{array}{l}\text { Andro } \\
\text { graphi } \\
\text { olide } \\
\text { conte } \\
\mathrm{nt} \\
(\mathrm{mg}) \\
\end{array}$ & $\begin{array}{l}\text { Herba } \\
\text { ge } \\
\text { Dry } \\
\text { Weig } \\
\text { ht } \\
(\mathrm{gm})\end{array}$ \\
\hline $\begin{array}{l}\text { Replicati } \\
\text { on }\end{array}$ & 1 & 2.72 & 20.26 & 0.17 & 4.93 & 0.018 & 0.001 & 05 & 0.02 & 0.17 & 3 & 0.294 & $\begin{array}{l}0.010 \\
7\end{array}$ & 0.010 & 8.34 & 0.002 & 4.31 \\
\hline $\begin{array}{l}\text { Treatme } \\
\text { nt }\end{array}$ & $\begin{array}{l}13 \\
3\end{array}$ & $\begin{array}{l}549.66 * \\
*\end{array}$ & $\begin{array}{l}645.02 \\
* *\end{array}$ & 0.55 & $59.95 * *$ & $\begin{array}{l}4878.2 \\
* *\end{array}$ & 0.307 & $\begin{array}{l}3.38^{*} \\
*\end{array}$ & 0.15 & $\begin{array}{l}20.2 * \\
*\end{array}$ & 0.41 & 0.282 & $\begin{array}{l}0.015 \\
5\end{array}$ & $\begin{array}{l}29.12 \\
* *\end{array}$ & $\begin{array}{l}198.6 \\
3 * *\end{array}$ & 0.258 & $\begin{array}{l}207.9 \\
55 * *\end{array}$ \\
\hline Error & $\begin{array}{l}13 \\
3 \\
\end{array}$ & 2.31 & 6.5 & 0.12 & 7.00 & 17.62 & 0.243 & 0.28 & 0.03 & 5.19 & 0.177 & 0.218 & 0.008 & 22.06 & 3.78 & $\begin{array}{l}0.000 \\
98\end{array}$ & 2.095 \\
\hline
\end{tabular}

$\mathrm{DF}=$ degree of freedom

*=Significant at $5 \%$ probability level

$* *=$ Significant at $1 \%$ probability level

Table.2 Estimation of genetic parameter for different traits in kalmegh

\begin{tabular}{|c|c|c|c|c|c|c|c|c|c|}
\hline \multirow[t]{2}{*}{ S.No. } & \multirow[t]{2}{*}{ Character } & \multirow[t]{2}{*}{ mean } & \multicolumn{2}{|l|}{ Range } & \multirow[t]{2}{*}{ GCV (\%) } & \multirow{2}{*}{$\begin{array}{l}\text { PCV } \\
(\%)\end{array}$} & \multirow[t]{2}{*}{$h^{2}(\%)$} & \multirow{2}{*}{$\begin{array}{l}\text { Genetic } \\
\text { advance }\end{array}$} & \multirow{2}{*}{$\begin{array}{l}\text { G A as } \% \text { of } \\
\text { mean }\end{array}$} \\
\hline & & & Min. & Max. & & & & & \\
\hline 1 & Days to $50 \%$ flowering & 126.76 & 95.00 & 168.00 & 13.05 & 13.11 & 99 & 33.94 & 26.77 \\
\hline 2 & Plant height $(\mathrm{cm})$ & 76.22 & 30.75 & 116.82 & 23.44 & 23.68 & 98 & 36.44 & 47.81 \\
\hline 3 & Stem Diameter $(\mathrm{cm})$ & 2.32 & 1.17 & 3.35 & 19.86 & 25.02 & 63 & 0.76 & 32.48 \\
\hline 4 & No. of secondary branches/plant & 33.82 & 22.00 & 44.50 & 15.21 & 17.11 & 79 & 9.43 & 27.87 \\
\hline 5 & No. of tertiary branches / plant & 145.94 & 34.75 & 322.75 & 33.48 & 33.90 & 99 & 101.19 & 69.33 \\
\hline 6 & Leaf width $(\mathrm{cm})$ & 1.53 & 0.52 & 3.35 & 11.65 & 34.36 & 11 & 0.12 & 8.13 \\
\hline 7 & Leaf length $(\mathrm{cm})$ & 6.42 & 2.41 & 9.15 & 19.37 & 21.09 & 84 & 2.36 & 36.67 \\
\hline 8 & Petiole length $(\mathrm{cm})$ & 1.03 & 0.16 & 2.84 & 23.52 & 29.94 & 62 & 0.39 & 38.05 \\
\hline 9 & No. of Nodes/plant & 22.15 & 14.75 & 29.50 & 12.40 & 16.11 & 59 & 4.36 & 19.66 \\
\hline 10 & Internodes length $(\mathrm{cm})$ & 2.74 & 1.22 & 4.00 & 12.48 & 19.78 & 40 & 0.45 & 16.23 \\
\hline 11 & No. of Seeds/pod & 11.29 & 10.33 & 11.84 & 1.58 & 4.43 & 13 & 0.13 & 1.16 \\
\hline 12 & Pod Length $(\mathrm{cm})$ & 1.82 & 1.64 & 2.21 & 3.37 & 5.97 & 32 & 0.07 & 3.92 \\
\hline 13 & Chlorophyll Content (spad) & 56.45 & 43.12 & 64.96 & 3.33 & 8.96 & 14 & 1.44 & 2.55 \\
\hline 14 & Herbage Fresh Weight (gm) & 36.42 & 12.60 & 52.70 & 27.11 & 27.63 & 96 & 19.95 & 54.78 \\
\hline 15 & Herbage Dry Weight (gm) & 29.49 & 6.17 & 46.40 & 34.40 & 34.75 & 98 & 20.69 & 70.15 \\
\hline 16 & Andrographiloide content (mg) & 1.05 & 0.32 & 1.81 & 34.12 & 34.25 & 99 & 0.74 & 70.02 \\
\hline
\end{tabular}




\section{Int.J.Curr.Microbiol.App.Sci (2017) 6(11): 1847-1855}

Fig.1 Components of variance, coefficient of variability, heritability and genetic advance

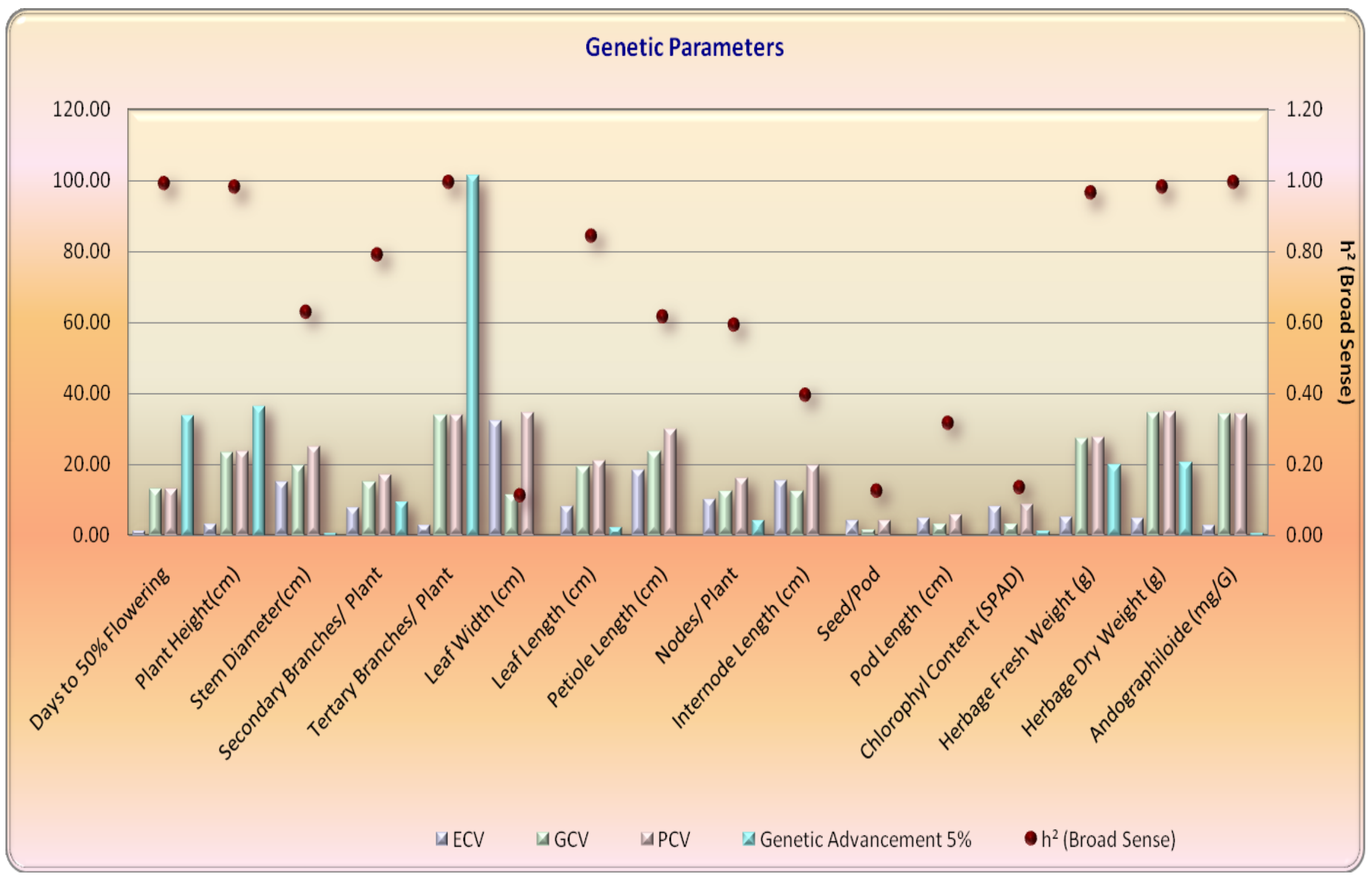


The low GCV and PCV were observed for number of chlorophyll content $(3.33 \%$ and $8.96 \%)$, pod length (3.37\% and $5.97 \%)$ and no. of seeds / pod $(1.58 \%$ and $4.43 \%)$.

\section{Heritability and genetic advance}

Heritability governs the resemblance between parents and their progeny whereas, the genetic advance provide the knowledge about expected gain for a particular character after selection. Heritability suggests the relative role of genetic factors in expression of phenotypes and also acts as an index of transmissibility of a particular trait to its off springs. However, the knowledge of heritability alone does not help to formulating concrete breeding programme, genetic advance along with heritability help to ascertain the possible genetic control for any particular trait. The nature and extent of the inherent ability of a genotype for a character is an important parameter determining the extent of improvement of any crop species. Heritability and genetic advance are the important genetic parameters for selecting a genotype that Permit greater effectiveness of selection by separating out environmental influence from total variability.

Heritability estimate provide the information regarding the amount of transmissible genetic variation to total variation and determine genetic improvement and response to selection. Heritability estimate along genetic advance are normally more useful in predicting the gain under selection than that of heritability alone. However, it is not necessary that a character showing high heritability will also exhibit high genetic advance (Johnson et al., 1955).

In the present investigation high magnitude of heritability was recorded for most of characters. The highest heritability was recorded for the character days to $50 \%$ flowering (99\%), no. of tertiary branches/plant (99\%), andrographiolide content (99\%), plant height (98\%), herbage dry weight (98\%), herbage fresh weight (96\%), leaf length (84\%), no. of secondary branches / plant $(79 \%)$, stem diameter $(63 \%)$, petiole length $(62 \%)$, no. of nodes / plant $(59 \%)$, internodes length $(40 \%)$, pod length $(32 \%)$, Chlorophyll content (14\%), no. of seeds /pod $(13 \%)$, leaf width (11\%). It indicates that these character is least influenced by the environment or therefore selection of such characters will be rewarded.

The heritability value alone however, provides no indication of the amount of genetic improvement that would that result from selection of superior genotypes. The heritability estimates would be reliable if it is limited in broad sense, additive and nonadditive gene effect are accompanied with high genetic advance. To facilitate the comparison of progress in various characters of different genotypes genetic advance was calculated as percentage of mean.

The magnitude of genetic advance as percentage of mean easy categorized as high $(>30 \%)$, moderate $(30 \%-10 \%)$ and low $(<10 \%)$. Genetic advance as percentage of mean was observed high for no. of tertiary branches / plant (101.19\%) followed by plant height $(36.44 \%)$, days to $50 \%$ flowering $(33.94 \%)$. It showed that the character is governed by additive gene and selection will be rewarded for the improvement of such characters.

Genetic advance as percentage mean was recorded as moderate for herbage dry weight (20.69\%), herbage fresh weight $(19.95 \%)$ and it was low for no. of secondary branches / plant $(9.43 \%)$, no. of nodes/ plant $(4.36 \%)$, leaf length $(2.36 \%)$, Chlorophyll content (1.44\%), stem diameter $(0.76 \%)$, andrographiloide content $(0.74 \%)$, internodes 
length $(0.45 \%)$, petiole length $(0.39 \%)$, no. of seeds / pod $(0.13 \%)$, leaf width $(0.12 \%)$, pod length $(0.07 \%)$. It indicate that these character governed by non-additive gene and heterosis breeding may be useful.

High heritability coupled with high genetic advance as percentage of mean was found in the character, andrographiolide content $(99 \%)$ $(70.02 \%)$, followed by no. of tertiary branches /plant (99\%) (69.33\%), herbage dry weight (98\%) (70.15\%), plant height (98\%) (47.81\%), herbage fresh weight (96\%) $(54.78 \%)$, leaf length $(84 \%)(36.67 \%)$ and no. of secondary branches / plant (79\%) (27.87\%) (Fig. 1). It indicates that most likely the $\mathrm{h}^{2}$ is due to additive gene effect or selection of such character may be effective. Moderate heritability coupled with moderate genetic advance as percentage mean was found in character stem diameter (63\%) (32.48\%), petiole length (62\%) $(38.05 \%)$, no. of nodes / plant $(59 \%)(19.66 \%)$. It indicates the existence of additive as well as non-additive gene action for the characters. Low heritability coupled with low genetic advance as percentage of mean was found in the character internodes length $(40 \%)(16.23 \%)$, pod length (32\%) (38.05\%), Chlorophyll content (14\%) $(2.55 \%)$, no. of seeds / pod $(13 \%)(1.16 \%)$, leaf width $(11 \%)(8.13 \%)$. It indicates selection of such character is not useful.

Analysis of variance Revealed significant differences among the kalmegh genotype for the Character viz., days to $50 \%$ flowering, plant height $(\mathrm{cm})$, no. of secondary branches / plant, no. of tertiary branches / plant, leaf length $(\mathrm{cm})$, No. of nodes / plant, chlorophyll content (spad), herbage fresh weight (g), herbage dry weight $(\mathrm{g})$. Whereas, characters, leaf width $(\mathrm{cm})$, petiole length $(\mathrm{cm})$, stem diameter $(\mathrm{cm})$, internodes length $(\mathrm{cm})$, pod length $(\mathrm{cm})$, no. of seeds / pod, andrographiloide content (mg).
The GCV and PCV was observed highest for herbage dry weight, Andrographiloide content (mg), No. of tertiary branches /plant, herbage fresh weight, petiole length, plant height and moderate GCV was recorded for most of the character viz., stem diameter, leaf length, no. of secondary branches / plant, days to $50 \%$ flowering, internodes length, no. of nodes / pod, leaf width, whereas, the low GCV, pod length, no. of seeds / pod, and chlorophyll. The GCV for average herbage dry weight, herbage fresh weight, andrographiloide content (mg), no. of tertiary branches, petiole length recorded high which shows considerable scope for yield improvement in present kalmegh gene pool.

High heritability coupled with high genetic advance as percentage of mean was found in the character no. of tertiary branches / plant, days to $50 \%$ flowering, andrographiloide content followed by herbage dry weight and plant height. It indicates that most likely the $\mathrm{h}^{2}$ is due to additive gene effect or selection of such character may be effective. The traits which showed moderate heritability coupled with moderate genetic advance as percentage mean indicate the role of additive as well as non-additive gene action for the characters in their expression.

\section{References}

Akbarsha, M.A., Manivannam, B., Hamid, K.S. and Vijayan, B. 1990. Antifertility effect of andrographis paniculata (Nees) in male albino rat. Indian $J$. Experimental Biol., 28(5): 421-426.

Kapil, A., Koul, I.B. Banjare, S.K. and Gupta, B.D. 1993. Antihepatotixic effect of major diterpenoid constituents of Andrograhis paniculata. Bioche Pharmacol., 46(1): 182-85.

Kumar Ashok, Semwal D.P., Bhatt K.C. and Raina A. 2014 Character ization of indigenous germplasm of Andrographis 
paniculata (Burm. f.) Wall. ex Nees for variability analysis. Indian Journals 6(4). 139:230.210

Lattoo, S. K., S. Khan, A. K. Dhar, D. K. Choudhary, K. K. Gupta, and P. R. Sharma. 2006. "Genetics and mechanism of induced male sterility in Andrographis paniculata (Burm. f.) Nees and its significance, Current Science. 91(4): 515-519.

Lin, F.L., Wu, S.J., Lee, S. C. and Ng, L.T. 2009. Antioxidant, antioedema and analgesic activities of Andrographis paniculata extracts and their active Constituent andrographolide. Phytotherapy Research. 23(7): 958964.

Minz, P.L. and Koche, Vijaya. 2012. Variation in morphological parameter and Andrographolide content in Andrographis paniculata collected from different provenances of Chhattisgarh.
Research Journal of Biotechnology. 7(4): 5714-5722.

Nagvanshi disha 2014. study of variability parameter in kalmegh (andrographis paniculata wall.). M.Sc. (Ag.) Thesis, indira gandhi krishi vishwavidyalaya Raipur (C.G).

Pandey, A.K. and Mandal, A.K. 2010. Variation in morphological characteristics and Andrographolide content in Andrographis paniculata of central India. Iranica Journal of Energy and Environment. 1(2): 165-169.

Shankar, R., Deb, S. and Sharma, B. K. 2012. Antimalarial plants of northeast India: An overview. J. Ayurveda Integr Med., 3(1): 10-16.

Zhang, J., Xie, W., Wang, Y., Zhao, X., (2015).Potential of Start Codon Targeted (Scot) Markers to estimate genetic diversity and relationships among Chinese Elymussibiricus accessions. Molecules 20:5987-6001.

\section{How to cite this article:}

Hema Devi, Hemant Dhuri, Alice Tirkey and Porte, S.S. 2017. Genetic Variability and Heritability Studies in Andrographis paniculata Wall. Ex Nees. Int.J.Curr.Microbiol.App.Sci. 6(11): 1847-1855. doi: https://doi.org/10.20546/ijcmas.2017.611.220 